\title{
Mitolojik ve Dinsel Bir Yükseliş Simgesi Olarak Merdiven Motifi
}

\author{
Dr. Öğr. Üyesi Necati SÜMER*
}

Atıf / (C- Sümer, N. (2018). Mitolojik ve Dinsel Bir Yükseliş Simgesi Olarak Merdiven Motifi, Çukurova Üniversitesi İlahiyat Fakültesi Dergisi, 18 (1), 257269.

Öz- Merdiven, kişiyi belli bir konumdan diğerine taşıyan araçtır. Bu konum, aşağıdan yukarı olabildiği gibi yukarıdan aşağı da olabilir. Gündelik hayatın basit ihtiyaçlarını karşılayan merdiven, mitoslarda ve bazı inançlarda önemli bir simgedir. Şamanın ayin yaparken ağaca tırmanmasını sağlayan bir yükseliş aracı olan merdiven, bazen de mitoslarda tanrıların dünyayla iletişim kurmak amacıyla yeryüzüne inmek için kullandığı bir vasıtadır. Kimi dinlerde ise merdiven, peygamberlerin rüyasında üzerinde meleklerin dolaştığını gördüğü bir iniş çıkış simgesidir. Birçok amaçla kullanılan merdiven, genellikle yükseliş simgesi olarak değer kazanmıştır. Insan veya tanrılar, çoğu zaman yedi basamaklı merdivenlerle göğe tırmanmayı tercih etmiştir. Gerek göğe yükselen hayali merdivenler gerekse de yeryüzünde yapılan kutsal mabetler yedi basamaklı merdiven biçimindedir. Birçok kültürde merdivene hem bu dünyada hem de öte dünyada bazı anlamlar ve değerler yüklenmiştir. Bu çalışmada merdivenin mitoslarda ve inançlarda taşıdığı roller üzerinde durulmuştur.

Anahtar sözcükler-Merdiven, yer, gök, tanrı, yükseliş

\section{$\S \S \S$}

\section{Giriş}

Bu çalışmada dinler tarihinde önemli bir araç olarak görülen merdiven simgesi üzerinde durulacaktır. Bu araç dinler ve mitler açısından genellikle

Makalenin gelişi: 13.03.2018; Yayına kabul tarihi: 12.06.2018

* Siirt Üniversitesi İlahiyat Fakültesi Dinler Tarihi Anabilim Dalı, e-posta: necatisumerr@gmail.com (ORCID: 0000-0002-7875-6671) 
yükselişle özdeşleşmekle birlikte onun hangi kültürde başka ne anlamlar ifade ettiği de önemlidir. İlkel kabilelerde, mitoslarda ve bazı inanç sistemlerinde merdivenin nasıl bir fonksiyon icra ettiğini ortaya koymak için dinler tarihinin mukayeseli yaklaşımıyla bu simgeyi ele almak gerekir. Bu çerçevede merdiven anlayışı bazı kültürlerden örneklerle işlenmeye çalışılacaktır.

\section{Merdiven}

Sözlükte bir yere çıkmaya veya bir yerden inmeye yarayan basamak dizisi olarak ifade edilir. ${ }^{1}$ Merdiven, ister ilkel ister medeni olsun birçok toplumda önemli bir simge olarak ifade bulur. Onun en temel özelliği, bir yükseliş simgesi olmasıdır. O, yeryüzünden fizikötesi âlemlere yükselmek için kullanılan önemli bir araçtır. Merdiven, bir var oluş tarzından başka bir var oluş tarzına geçişi olanaklı kılar. Dinler tarihçisi Mircea Eliade'a göre merdiven bağlamında tırmanma veya yükselme, mutlak gerçeğe giden yolu simgeler. ${ }^{2}$

Yeryüzünden semavi âlemlere merdivenle ulaşılabileceği fikri birçok kültürde mevcuttur. Bazı kültürlerde merdiven; yer ve gök arasında iletişimi sağlarken bazı kültürlerde ise o, ayinlerde ve cenaze merasimlerinde önemli rol oynayan bir simgedir. Fakat merdiven mitoslarda, ilkel kabilelerde ve bazı inanç sistemlerinde genellikle yükseliş vazifesini görür.

\section{Mitoslarda Merdiven}

Mitos, kutsal öykü demektir. O, en eski zamandaki olmuş bitmiş olayları anlatır. Doğaüstü varlıkların yaptığı kahramanlıkların ve yaratıcı etkinliklerin öyküsüdür. Bir şeyin nasıl yaratıldığı veya var olduğu mitosun problemidir. Mitosun işlevi, bütün ritlerin ve anlamlı insan etkinliklerinin örnek teşkil edecek modellerini ortaya koymaktır. Mitostaki kişiler genellikle tanrılar veya doğaüstü varlıklardır. Mitos, bazı şeylerin niçin ve nasıl yaratıldığını açıklayarak insanlara yol gösterir. Dolayısıyla o, dünyanın, insanın ve yaşamın doğaüstü kökenini açıklayan bir öykü olarak ifade edilebilir. Bu öykü, model göstererek ilk gerçeğin yeniden yaşatılmasını sağlar. Bunu da mecazlı bir dille yapar. ${ }^{3}$

Merdiven, birçok mitosta çoğu zaman yer ile gök arasında bağlantıyı sağlayan bir simgedir. Örneğin Babil mitolojisinde yeryüzü, etrafı tuzlu suyla çevrili düz bir disk olarak görülürdü. Buradan yeraltına ancak ufuklardan aşağı

Türkçe Sözlük, "Merdiven”, TDK Yayınları, 9. Baskı, Cilt 2, Ankara, 1998, s.1537.

2 Mircea Eliade, Imgeler ve Simgeler, çev.: Mehmet Ali Kılıçbay, Gece Yayınları, Ankara, 1991, s.29.

3 Mircea Eliade, Mitlerin Özellikleri, çev.: Sema Rifat, Alfa Yayınları, İstanbul, 2017, s.34-35. 
giden bir merdivenle inilirdi. Böylece çift sürgülü bir kapıdan aşağıya varılırdı. Güneş, bu kapıdan aşağıya süzülürdü. Ayrıca yeraltından gökyüzüne açılan farklı bir merdiven daha vardı. Yalnızca bu merdiven aracılığıyla yeryüzüne çıkmak mümkündü. Yine Sümer'de ve Babil'de ölüler yeraltına gömülürdü. Merdiven, bu kültürlerde yerüstündekiler ve altındakiler arasında iletişimi sağlayan bir araç olarak görülürdü. Mezopotamya mitoslarında merdivenin bu işlevi onun iki düzey arasında bir köprü işlevi gördüğünü ortaya koymaktadır. ${ }^{4}$

Merdiven, Mezopotamya'da Ziguratlarla da özdeşleşmiştir. Nitekim MÖ 2200 yıllarından itibaren Mezopotamya'da piramit biçiminde basamaklı birçok Zigurat inşa edilmiştir. Bunlar, bir çeşit tapınak kuleleridir. Bu kulelerin en üstünde şehrin baş tanrısı için yapılan türbeler bulunurdu. Buraya dıştan ulaşım üç katlı merdiven ya da spiral bir yokuş aracılığıyla gerçekleşirdi. Ayrıca içten de merdivenler sayesinde zirveye ulaşılırdı. ${ }^{5}$ Gerek Sümer gerekse de Babil Ziguratları genellikle basamaklı piramit şeklindeydi ve her bir piramidin yedi basamağı vardı. Örneğin Sümer Kralı Gueda'nın tapınağına "dünyanın yedi kısmının evi” denilirdi. Bu ismin verilmesinin sebebi, yedi göksel kürenin ziyaretçilerini hatırlatmaktı. Dolayısıyla merdiven, Mezopotamya kültürleri için yükselişi simgeleyen önemli bir motiftir. O, gökte olanın kutsalığına varmayı ifade etmiştir. Bu kültürde merdivenlerin yedi basamaklı oluşu bilgeliğe yükselme anlamını da taşımaktaydı. Dolayısıyla merdivenin Mezopotamya uygarlıkları için hakikate aracılık eden bir yükseliş aracı olduğu da ifade edilebilir. 6

Japon mitoslarında merdiven, cennetin yüzen köprüsünün üzerinde duran bir araç olarak ifade edilir. Kojiki ve Nihongi'ye dayandırılan bu mitoslara göre İzanagi ve İznami adlı iki tanrı, dengesi bozulan ve sürüklenen dünyayı sağlamlaştırmak ve onu dirençli kılmak için bir çabaya girer. İkisi bir okyanus üzerine gelir. Mitosa göre okyanusun üzerinde gökkuşağı şeklinde bir köprü vardır. Bu tanrılar "Kutsal Merdivenler" olarak bilinen cennetin yüzen köprüsü üzerinde durur. Kahraman ilahlar, köprü üzerinden okyanusun tuzlu suyunu yapışkan ve yoğun hale gelene kadar karıştırırlar. Sular belli bir yoğunluk kıvamına gelince tanrılar mızrağı çıkarıp buraya saplar. Mitosa göre mızrağın ucundan bir lapa düşer ve ada oluşur. Tanrılar "Kutsal Merdivenler" aracılığıyla cennetten bu adanın üzerine inip ortasında sütun bulunan sekiz

4 Jeremey Black ve Anthony Gren, Mezopotamya Mitolojisi Sözlügü, Tanrılar, Ifritler, Semboller, Aram Yayıncılık, İstanbul, 2013, s.129.

5 Jeremey Black ve Anthony Gren, s.239.

6 Annemarie Schimmel, Sayıların Gizemi, çev.: Mustafa Küpüşoğlu, Kabalcı Yayınevi, İstanbul, 2000, s. 142 . 
kulaç uzunluğunda bir ev yaparlar. Böylece buradan dünyanın temelini sağlamlaştırmaya çalışırlar. Burada merdivenler, yeryüzü ile gökyüzü arasında olumlu bir işlev görür. $\mathrm{O}$, tanrıların iniş ve çıkışlarına yardımcı olan bir araçtır. ${ }^{7}$

\section{Dinlerde Merdiven}

Merdiven sadece mitoslarda değil ilkel veya medeni birçok toplumun inançlarında da önemli bir yükseliş simgesidir.

\section{a) İlkel Kabile Dinlerinde Merdiven}

İlkel kabileler avcılık, toplayıcılık, balıkçılıkla geçinen ve belli bir üretim sistemine sahip olmayan topluluklardır. ${ }^{8}$ Ilkel kabilelerin belli bir inanç sistemi, kutsal kitabı ve kurucusu da yoktur. Bütün üyeleri kabilenin dinine bağlı olan bu gruplarda ata ruhlarına saygı, tabiat olaylarını kontrol altına alma ve yüce bir yaratıcı gibi birtakım inançlar vardır. ${ }^{9}$

İlkel kabileler arasında merdivenin değeri ile ilgili birçok inanış vardır. Örneğin Malenezya adası olan Malekula'da domuz kurban törenleri önemli yer tutar. Bu törenlerin adı Maki'dir. Törenler on beş yıldan otuz yıla kadar sürer. Hırs ve ün kazanmaya dayalı bu törenlerin amacı, insan ırkının çoğalmasını sağlamaktır. Bu tören çerçevesinde köyün erkekleri ellerinden geldiğince kurban edilecek birçok domuz avlamaya çalışır. İlkeller, böyle yaparak hem bu hem de öte dünyada yer kazanmaya çalışırlar. Malekulalı öldüğünde taş bir mezara konulur. Bu mezar, kadın rahmini temsil eder. Ölü, buradan öte dünyaya yükselmeye çalışır. Bu yükselişe yardım eden şey güç merdivenleridir. Ölü, bu merdiven aracılığıyla öte dünyaya açılan kapının girişine gelir. Böylece ölüler ülkesine doğru uzun bir yolculuk başlar. Bu yolculuğun ilk kısmında başında dişi bir gardiyan olan bir kapı vardır. O, labirentler şeklinde yollar çizer. Ölü, bu labirentleri hatırlayıp tek tek silmeye çalışır. Ayrıca o, hayattayken Maki törenlerinde kurban ettiği domuzları da burada sunmak zorundadır. Çünkü dişi tanrıca veya gardiyan bu kurbanı yemektedir. Tanrıça, bu kurbanları yedikçe ölü, öte dünyaya uzanan merdivenin basamaklarını sorunsuzca tek tek çıkmaktadır. Bu yolculuğun bir benzeri, yaşayanlar tarafından da ölünün mezarı başında temsili olarak canlandırılır. Bu şekilde öte dünyaya mer-

7 Donald A. Mazkenzie, Çin ve Japon Mitolojisi, çev.: Koray Akten, İmge Kitabevi, Ankara, 1995, s290.

8 Baki Adam, "Din Hakkında Genel Bilgiler", Dinler Tarihi Elkitabı, Ankara: Grafiker Yayınları, 2015, s.51-52.

9 Hammet Arslan, "Afrika Topluluklarında Tabiat Kültü ve Tabii Unsurlara Atfedilen Güçler", Bartın Üniversitesi İslami Illimler Fakültesi Dergisi, 4/8, (Aralık-2017): 2-3. 
divenle yükselişte otuz yıl boyunca yapılan domuz kurbanları törenlerinin ne denli önemli olduğu vurgulanmış olur. ${ }^{10}$

On altıncı yüzyılda Kuzey Amerika kıtasındaki ilkel kabileler arasında Eski Meksika dini adı verilen önemli bir yerel inanç vardır. Bu inançta zaman zaman Tanrı'nın öldürülmesi söz konusudur. Tanrı'nın öldürülmesi töreninde bir insan temsili olarak bu törenlerde kurban edilirdi. Meksika yerlileri Tanrı olduğunu düşündükleri bir kişiyi putlarına kurban etmek için onu esir alıp törene hazırlarlardı. Bu süre zarfında esir yedirilip içirilir ve semiz bir hale getirilirdi. İyice şişmanlayan esir artık kurban edilmesi gereken bir Meksika Tanrısı haline gelirdi. Kurban edilmeden önce bu kişi, piramit şeklinde merdivenlerle yükselen bir tapınağın önüne getirilirdi. Eline flütler verilen kişi, tırmandığı merdivenin her bir basamağında bir flütü kırardı. Bu kişi en tepeye varınca rahip tarafından bir taşın üzerine oturtulurdu. Törenin sonunda taş bir bıçakla göğsü yarılan kişinin kalbi çıkarılarak güneşe sunulurdu. Böylece merdivenle en yüksek noktaya çıkarılan kişi, zirvede putlara sunulan cansız bir yığın haline gelirdi. Merdiven burada yükselişi sağlayan bir araç olarak törenlerin vazgeçilmez bir ögesi olmuştur. Onun, her basamağı kutsal bir yükseliş aracını temsil etmektedir. ${ }^{11}$

Sibirya'da Amur nehrinin kuzey kıyısında yaşayan ve Tunguz dilini konuşan Goldiler, ölü ruhlarına önem veren bir kabiledir. Goldilere göre ölen bir kimse, son cenaze töreni yapılana kadar üç ya da dört yıl boyunca hala canlı sayılır. Bu kişiye yiyecek ve tütün vermeye devam edilir. Goldi kabilesi, son ziyafet yapıldıktan sonra ölünün ruhunun Buni adı verilen ölüler ülkesine gideceğine inanır. Fakat bu gidiş, ancak şamanların yapacağı törenlerle gerçekleşebilir. Goldiler, intihar edenlerin ve gömülmemiş ölülerin ruhlarından korktukları için sürekli olarak çeşitli törenler düzenlerler. Bu anlayış Ruslar, Norveçliler, Eskimolar ve bazı Kızılderili kabileler arasında da yaygındır. Bu kültürlerde ilk törenlerde ölünün ruhunun geri gelmemesi için fısıltı halinde sürekli ona telkinlerde ve öğütlerde bulunulur. Şaman, çeşitli tekniklerle ölünün ruhunu yakalar ve onu bir yastığın içine saklar. Ölünün ruhu, son ziyafet verilene kadar çeşitli törenlerle teskin edilir. Son ziyafet anı geldiğinde şaman, ruhlarını kendine çağırır. Daha sonra onları temsil eden vahşi hayvanlarla kuşları taklit eder. Törenin sonunda şaman, bir merdivenden tırmanır ve ölüler ülkesinin yolunu bulmak için sağa sola bakınır. Ölüler ülkesinin yolunu bulan

10 Joseph Campbell, İlkel Mitoloji, Tanrı'nın Maskeleri, çev.: Kudret Emiroğlu, İmge Kitabevi Yayınları, İstanbul, 1992, s.430-434

11 James G. Frazer, Altın Dal, Dinin ve Folklorun Kökenleri, II, çev.: Mehmet H. Doğan, Payel Yayınları, İstanbul, 1992, s.203-207. 
şaman, merdivenden geri inerek içinde ruh bulunan yastığı ateşe atar. Törenden sonra artık ölü unutulur. Böylece merdiven, bu dünya ile öte dünya arasında ulaşımı sağlayan bir yükseliş aracı vazifesini görmüş olur. ${ }^{12}$

\section{b) Amerika ve Asya Dinlerinde Merdiven}

Orta Amerika inançlarında gökyüzü, renkli yatay bir çizgi ya da üst üste gelen çizgiler biçiminde bir kubbe olarak algılanır. Bu kubbe veya çatı, bütün evreni içine alır. Buradaki inanca göre dünya büyük bir kozmik felaket yaşamış ve gökyüzü yeryüzünün üzerine çökmüştür. Fakat gökyüzü bir takım nesneler veya tanı kahramanlar aracılığıyla tekrar kaldırılmıştır. Bu nesneler ağaç veya baltadır. Kahraman tanrılar ise Maya ve Azteklerin tanrılarıdır. Bu destekler, gökyüzü ile yeryüzü arasında önemli bir kaldırma ve temas işlevi görür. Buradaki inanca göre dünyanın merkezinden gökyüzüne yükselen bir piramit, merdiven ve asılı bir halat vardır. Bu merkezde törenler düzenlenir ve gökyüzüne bu araçlardan biriyle çıkılır. Asıl iletişim kuran ve göğe yükselmeyi kolaylaştıran araçlar bunlardır. ${ }^{13}$

Eski Türk geleneğinde özellikle Macarlar arasında insanüstü güçlere sahip olanların yedi yaşına geldiğinde mutlaka bir merdivene tırmanması gerektiği şeklinde bir inanç vardır. Bu inanış, merdivenin bir yükseliş aracı olarak önemine vurgu yapmaktadır. Yine Tunguzların şamanı, göğe yolculuk esnasında bazen Dünya Ağacı'nı merdiven olarak kullanır. Bu kutsal ağacın gövdesinde veya dallarında bulunan kertikler, tırmanmak için basamak işlevini görür. Kertiklerin her biri, göğün katlarını sembolize eder. Dolayısıyla şamanın her bir kertiğe tırmanması onun gökte farklı bir katmana ulaşması anlamına gelir. Şaman, hasta olan kişinin hastalığını emip tükürdükten sonra kurban edilmiş hayvanın ruhunu merdiven veya ağaç vasıtasıyla göğe çıkarır. Bir tür hastalığı iyileştirme terapisi olan bu ayin, şamanın göğe doğru tırmanmasıyla son bulur. Şaman, bir merdiven veya ağaçla göğe çıktığı gibi yerin altına da inebilmektedir. Özellikle yedi basamaklı bir merdiven veya yedi kertikli bir ağaç, şamanın bütün engelleri aşarak yeraltına indiği önemli bir simgedir. ${ }^{14}$

Eski Türk kültürüne benzer şekilde kurban törenleri esnasında merdiven aracılığıyla göğe yükselme geleneği Hint Kıtasında da vardır. Şaman

12 Julian Baldick, Hayvan ve Şaman, Orta Asya'nın Antik Dinleri, çev.: Nevin Şahin, Hil Yayınları, İstanbul, 2010, s.164-179.

13 Yves Bonnefoy, Antik Dünya ve Geleneksel Toplumlarda Dinler ve Mitolojiler Sözlüğü, çev.: Levent Yılmaz, I, Cilt, Dost Kitabevi, Ankara, 2000, s.344.

14 Yaşar Çoruhlu, Türk Mitolojisinin Ana Hatları, Kabalcı Yayınevi, İstanbul, 2000, s.67-72; Baldick, s.179. 
törenleri gibi burada Durohana kurban törenleri yaygındır. Merasimde bazen rahip tek başına bazen de eşiyle bir ağaç veya merdiven aracılığıyla göğe doğru tırmanır. Rahip bu ritüelde eşine özellikle üç defa "hadi gel, göğe çıkalım" şeklinde seslenmek zorundadır. En tepeye çıkınca da oraya dokunur. Ayrıca direk veya merdiven, dünyanın merkezinden göğe uzanan mitolojik kutsal bir ağaca vurgu yapar. Yer ile göğü birleştiren bu merdiven motifi, tanrısal âleme ulaşmayı temsil eder. Rahip; ağacın veya merdivenin en tepesine çıktığında ellerini iki yana açarak "göğe ulaştım ve ölümsüz oldum" şeklinde çığlık atar. Böylece o, daha önce kurban da sunarak yer ile gök arasında kendine köprü yapmış olur. ${ }^{15}$

\section{c) Hint, Çin, Mısır ve İran Dinlerinde Merdiven}

Hinduizm'in yayıldığı yerlerden olan Nepal'de Holi Bayramı kutlanır. Burada altı gün boyunca yapılan festivalde ana Tanrıça' altarının kenarına on metreden yüksek bir şemsiye dikilir. Buraya dikilen direk kutsaldır. Göğe yükselişi temsil eden direğin altında insanlar tütsü yakar; pirinç, çiçek ve renkli tozlar serper. Direk onlar için baharın müjdecisidir. İnsanlar bu etkinlikle kendinden geçer ve mutlu olurlar. ${ }^{16}$

Budizm'de de aydınlanan kişi meditasyon halindeyken göğe ruhsal bir yolculuk yapar. Özellikle Buda, yedi göğü simgesel olarak geçer ve böylece kozmosu aşar. Budist inancında Buda'nın bu aşamaları sembolik bir merdivenle geçtiğine inanılır. Bu yolculuğun benzerini Budist yogiler de meditasyonla yapmaya çalışır. Onların da üzerinde durduğu yükseliş aracı merdivendir. ${ }^{17}$

Eski Çin dinlerinde merdiven yer ile gök arasında bağlantıyı sağlayan bir yükseliş aracıdır. Özellikle Şeftali Ağacı, Çin dinsel geleneğinde uzun yaşamın ve ölümsüzlüğün sembolü olarak görülür. Çinliler, bu ağacın bir merdiven olarak yeryüzü ile gökyüzü arasında ulaşımı sağladığına inanır. Buna benzer diğer bir ağaç da Chien- Mu'dur. O, Çin inanışında yer ile gök arasında bağlantı sağlayan merdiven biçimindeki diğer ağaçtır. Bu ağacın evrenin merkezinde olduğu kabul edilir. Dalları olmayan bu ağacın göğe doğru yaklaşık 300 metre uzunluğunda olduğu ifade edilir. ${ }^{18}$ Ayrıca Çinliler, göğe ulaşmak ve kaderlerini ele geçirmek için de merdiven kullanırlar. Çin mitoslarına göre

15 Mircea Eliade, Şamanizm, Illkel Esrime Teknikleri, çev.: İsmet Berkan, İmge Kitabevi Yayınları, Ankara, 1999, s.441-442.

16 Hammet Arslan, "Holi: Hindu Bayramı", Dokuz Eylül Üniversitesi Illahiyat Fakültesi Dergisi, 1/39, (2014): 208.

17 Eliade, Şamanizm, s.444.

18 Jeremy Roberts, Chinese Mythology A to Z, Facts on File Press, New York, 2004, s.16; 93.

ÇÜiFD, 2018, cilt: 18, sayı: 1, ss. 257-269 
ölümsüz bir kadın gökten kocasını ve oğlunu indirmek için bir merdiven veya aşağı sarkıtılmış bir ip kullanır. Ayrıca Eski Çin inanışlarında tanrısal vahiylerin, doğaüstü güçlerin ve ölümsüzlüğün ip, merdiven ve ağaç gibi nesneler aracılığıyla gökten yeryüzüne indirildiğine inanılır. ${ }^{19}$

Merdiven, eski Mısır inancında da önemli bir motiftir. Mısır hanedanın beşinci Kralı olan Firavun Unas'ın; Tanrı Re ve Horus'un güvencesi altında merdivenle göğe çıktığına inanılır. Mısırlılar, Unas'ın bu şekilde göksel tanrılarla iletişimi geçtiğine inanırlardı. ${ }^{20}$ Eski Mısır kültürüne benzer şekilde Sabiilikte merdiven gökle ilişkilendirilir. Sabiilikte mitolojik bir şahsiyet olan Dinanukht, sulak bir yerde otururken kendisine Disa adlı başka bir mitolojik figür gelir. Ona Tanrı, doğruluk, ışık, aydınlık, gerçek, karanlık ve yok oluştan söz eder. Dinanukht, bu kavramlar üzerinde birtakım sorgulamalar yapar. Zihni yorulan bu mitolojik şahsiyet, derin bir uykuya dalar. Diğer dinlerde olduğu Tanrı ile peygamberler arasında iletişimi sağlayan Din Milik Utra isimli bir elçi gelir. Dinanukht, bir merdivenle Tanrı'nın yanına çıkarılır. Bu sebeple Sabii kutsal literatüründe merdiven için "sumbilta" yani ilahi âleme yükselten veya götüren anlamındaki kavram kullanılır. Yükseliş aracı olarak merdivenin yanında bazen rüzgâr ve fırtına da vardır. Bu araçlar sayesinde Dinanukht, Tanrı'nın yanına yani semavi âleme çıkarak kafasındaki bütün soruların cevabını bulur. $\mathrm{O}$, bu şekilde hakikate ulaşır. Kutsal bilgiyi alan kahraman yeryüzüne gelip insanları aydınlatır. ${ }^{21}$

Mitraizm'de göğe ya da tanrısal âleme yükseliş önemli bir aşamadır. Rahip adayı, yedi basamaklı bir merdivenden tırmanarak göğe ulaşmak zorundadır. Adaylar, bu basamağı tek tek ve ağır bir şekilde tırmanır. Yedi basamağın sonuna gelindiğinde rahip adayı yedi kat semayı geçmiş olur. Buradaki yükseliş, tamamen ruhsal ve semboliktir. Mitraizm'de merdiven motifi, diğer inançlarda olduğu gibi mükemmelliğe veya olgunluğa eriştiren bir vasıtadır. ${ }^{22}$ Mitraizm'de tören merdiveninin yedi basamağının olması ve her basamağın farklı bir madenden yapılması ilginçtir. Bu bilgiyi aktaran ikinci yüzyıl Yunan filozoflarından Kelsus'a göre birinci basamak kurşundandı. Ayrıca o, Satürn gezegenini sembolize ederdi. İkincisi, Venüs gezegenini temsilen ka-

19 Yves Bonnefoy, Antik Dünya ve Geleneksel Toplumlarda Dinler ve Mitolojiler Sözlüğü, çev.: Levent Yılmaz, II. Cilt, Dost Kitabevi, Ankara, 2000, s.680-721.

20 Pat Remler, Eygptian Mythology A to Z, Facts of File Press, New York, 2006, s.175-176.

21 Şinasi Gündüz; Yavuz Ünal ve Ekrem Sarıkçıoğlu, Dinlerde Yükseliş Motifleri ve İslam'da Miraç, Vadi Yayınları, Konya, 1996, s.51-52.

22 Mircea Eliade, Patterns in Comparative Religion, Trans. Eng. Rosemary Sheed, Sheed and Ward Pulishing, New York, 1958, s.23-40; Gündüz vd., s.54-55. 
laydandı. Üçüncü basamak tunçtandı, Jüpiter ile ilişkiliydi. Dördüncüsü, Merkür'e atfen demirdendi. Beşinci basamak para alaşımındandı ve Mars'ı simgelerdi. Altıncısı, gümüştendi ve ay sembolüyle ilişkiliydi. Son olarak yedinci basamak altındandı ve Güneş'i temsil ederdi. Kelsus'a göre aslında sekizinci bir basamak daha vardı. O da sabit yıldızlar küresini temsil etmekteydi. Neticede rahip adayı, yedi basamağı tırmandıktan sonra artık yedi göğü geçmiş olurdu. Böylece sekizinci basamakta evrenin merkezi ile en yüksek gök katı arasında sembolik iletişim sağlanırdı. Bütün basamakları tırmanıp zirveye ulaşan aday, sırra veya hakikate erişirdi. ${ }^{23}$

\section{d) Semitik Dinlerde Merdiven}

Semitik dinlerden olan Yahudilikte merdiven yükseliş bağlamında önemli bir simgedir. Eski Ahit'in Tekvin bölümü, merdiven motifinin işlendiği yerlerden biridir. Bu bölümdeki pasajlarda anlatılanlara göre Yakup peygamber, Esav tarafından takip edilmekten korktuğu için Şekem yolundan sapıp Luz şehrine gelir. Üzerinde giysi olmadığı için burada konaklayamaz. Bunun üzerine şehrin dışında bir yer olan Beytel'de geceler. Burada başını bir taşın üzerine koyup uyur. Rüyasında yer üzerine dikilmiş göklere kadar uzanan bir merdiven görür. Cennetle yeryüzü arasında temsili bir tırmanma aracı olarak ifade edilen bu merdivenin üzerinde melekler inip çıkmaktadır. Yakup peygamber, rüyasında Tanrı Yehova'nın da bu merdiven üzerinde durduğunu görür. Yehova ona, “ Atan İbrahim'in ve İshak'ın Tanrısı benim. Üzerinde yattığın toprağı sana ve soyuna vereceğim. Soyun artacak ve yeryüzündeki bütün halklar soyunla kutsanacak. Ben hep seninle olacak ve seni koruyacağım." der.24

Yahudiler açısından Beytel, Yakup peygamberin rüyasında meleklerin ve Yehova'nın merdiven üzerinde görüldüğü yer olması ve buranın kutsanmasından dolayı önemlidir. Nitekim bu kutsallıktan dolayı Yahudiler buraya Cennetin Kapısı adını vermişlerdir. ${ }^{25}$ Yine Yahudilerin buraya gelirlerinin onda birini bağışlaması Yakup peygamberin Beytel'de başından geçen bu olaylar sebebiyledir. Yakup peygamberin başını üzerine koyduğu taş da kimi Yahudiler açısından Mesihi sembolize ettiği için önemlidir. Çünkü Eski Ahit'te Davut'un Filistli usta savaşçı Golyatla mücadele ederken bu taşı kullandığı ifade edilir. Davut, kılıcı olmadan bu taşla güçlü dövüşçüyü yenmiş ve muzaffer

23 Eliade, Imgeler ve Simgeler, s.30-31.

24 Tekvin, 28: 10-22.

25 Howard Schwartz, Tree of Souls, The Mythology of Judaism, Oxford University Press, New York, 2004, s.356. 
olmuştur. Dolayısıyla Yakup peygamberin üzerinde rüya gördüğü bu taş, Mesih Davut'a da vurgu yapmaktadır. ${ }^{26}$

İslam inancında merdiven göğe yükselişi simgeleyen bir araçtır. Örneğin Kuran-ı Kerim'de Allah, inanmayanların tavrı karşısında peygambere, eğer insanlar ümmet olarak birleşmeselerdi Rahman'ı inkâr edenlerin evlerine gümüşten tavanlar ve onların üzerine çıkacakları merdivenler yapacağından bahseder. ${ }^{27}$ Başka bir ayette ise Allah peygambere, eğer onların yüz çevirmeleri sana ağır geldiyse bir delik açıp yerin dibine inerek veya bir merdiven kurup göğe çıkarak onlara bir mucize getirmeye gücün yetiyorsa durma, yap diye seslenir. ${ }^{28}$ Diğer bir ayette ise Allah yine inanmayanlara onların kendi vasıtasıyla ilahi vahyi dinleyecekleri bir merdiveni mi var diye sorar. ${ }^{29} \mathrm{Bu}$ ayetlerin tamamı, İslam'ın kutsal kitabında merdiven simgesinin bir yükseliş motifi olarak kullanıldığını göstermektedir. Cuma günleri hutbeyi veren din görevlisinin merdivenleri ağır ağır tırmanarak minbere çıkması yine de merdiven aracılığıyladır.

\section{Sonuç}

Merdivenin en temel özelliği bir yükseliş aracı olmasıdır. O, bir yerden başka bir yere taşıyıcılık veya iletişim görevini görür. Merdiven, ağaç ve ip gibi diğer bazı araçlarla birlikte ifade edilir. Yükseliş imgesine vurgudan dolayı merdiven, ilkel veya medeni birçok toplumun mitosunda ve inancında kendine yer bulmuştur. $O$, ilkellerin inancında şamanın ritüllerini yerine getirmesi için gerekli olan bir araçtır. Davulla ayinlerde coşan şaman, merdivene tırmanarak ağacın tepesine çıkar. Böylece ruhlarla iletişim kurar. Dolayısıyla merdiven, şamanın ruhlarla ve kutsalla olan ilişkisini sağlayan bir ulaşım nesnesidir. Merdiven olmadığında onu temsil eden araç genellikle ağaçtır. Fakat burada önemli olan merdivenin bir yükseliş nesnesi olması ve onun insanla kutsal arasında bir ilişki sağlamasıdır.

Merdiven, ilkeller için neyse uygar toplumlar için de odur. Mezopotamya inançlarında Zigguratların tepesine çıkmayı sağlayan bu araç Amerika ve Asya inançlarında insan ile kutsalın bağlantısını sağlayan dinsel bir simgedir. Hint, Çin, Mısır ve İran'da farklı nesnelerle özdeşleştirilen merdiven yine

26 Robert Graves ve Raphael Patai, Ibrani Mitleri, Tekvin-Yaratılış Kitabı, çev.: Uğur Akpur, Say Yayınları, İstanbul, 2009, s.296; 1. Samuel, 17: 1-50; Arthur H. Williamson, Apocalypse Then, Prophecy and the Making of Modern World, Preager Publishers, London, 2008, s.207.

27 Zuhruf, 43: 32.

28 En'am, 6: 35.

29 Tur, 52: 37. 
Tanrı ile insan arasındaki iletişimi sağlar. Bu kültürlerde mabetler merdiven aracılığıyla tanrıların evine açılır. Bu merdivenlerin her bir basamağının ifade ettiği anlamlar vardır. Dolayısıyla bir yükseliş simgesi olan merdiven bu kültürlerde hem aracılık hem de kutsalık vazifesi görür. Semitik dinlerden olan Yahudilikte merdiven, Eski Ahit'te Yakup peygamberin rüyasında üzerinde meleklerin inip çıktığını gördüğü kutsal bir yükseliş aracıdır. İslam için merdiven peygamberin miraca çıkışını sağlayan ve camilerde minbere ulaşılmasını sağlayan bir yükseliş motifidir.

Bu çerçevede merdiven ister ilkel ister uygar olsun hemen hemen her toplumun mitsel ve dinsel inancında yeri olan bir simgedir. Onun bütün toplumlarda ortak olan özelliği ise yükseliş aracı olmasıdır. Merdiven, insanı kutsala ulaştıran bir araç olarak iyiye ve güzele ulaşmayı temsil eder. İnsanlar veya diğer varlıklar, kutsala ulaşmak istediklerinde ona tırmanırlar. Kutsala çıkan bu merdivenin her basamağının bir anlamı ve değeri vardır. Bu anlam, kültürden kültüre farklılık gösterir. Sonuç olarak merdiven, yer ile gök veya insan ile kutsal arasındaki teması sağlaması bakımından önemli bir simgedir.

\section{Kaynakça}

Adam, Baki, "Din Hakkında Genel Bilgiler", Dinler Tarihi Elkitabı, Ankara: Grafiker Yayınları, 2015.

Arslan, Hammet, "Afrika Topluluklarında Tabiat Kültü ve Tabii Unsurlara Atfedilen Güçler", Bartın Üniversitesi İslami İlimler Fakültesi Dergisi, 4/8, (Aralık-2017): 2-16.

, "Holi: Hindu Bayramı", Dokuz Eylül Üniversitesi Illahiyat Fakültesi Dergisi, 1/39, (2014): 181-220.

Baldıck, Julian, Hayvan ve Şaman, Orta Asya'nın Antik Dinleri,çev.: Nevin Şahin, Hil Yayınları, İstanbul, 2010.

Black Jeremey ve Anthony Gren, Mezopotamya Mitolojisi Sözlüğü, Tanrılar, Ifritler, Semboller, Aram Yayıncılık, İstanbul, 2013.

Bonnefoy, Yves, Antik Dünya ve Geleneksel Toplumlarda Dinler ve Mitolojiler Sözlüğü, çev.: Levent Yılmaz, I, Cilt, Dost Kitabevi, Ankara, 2000.

-Antik Dünya ve Geleneksel Toplumlarda Dinler ve Mitolojiler

Sözlüğü, çev.: Levent Yılmaz, II. Cilt, Dost Kitabevi, Ankara, 2000.

Campbell, Joseph, IIlkel Mitoloji, Tanrı'nın Maskeleri, çev.: Kudret Emiroğlu, İmge Kitabevi Yayınları, İstanbul, 1992. 
Çoruhlu, Yaşar, Türk Mitolojisinin Ana Hatları, Kabalcı Yayınevi, İstanbul, 2000.

Eliade, Mircea, Patterns in Comparative Religion, trans. Eng. Rosemary Sheed, Sheed and Ward Pulishing, New York, 1958.

, Imgeler ve Simgeler, çev.: Mehmet Ali Kılıçbay, Gece Yayınları, Ankara, 1991.

---------------, Şamanizm, İlkel Esrime Teknikleri, çev.: İsmet Berkan, İmge Kitabevi Yayınları, Ankara, 1999.

2017.

Mitlerin Özellikleri, çev.: Sema Rifat, Alfa Yayınları, İstanbul,

Frazer, James G., Altın Dal, Dinin ve Folklorun Kökenleri, II, çev.: Mehmet H. Doğan, Payel yayınları, İstanbul, 1992.

Graves Robert ve Raphael Patai, Ibrani Mitleri, Tekvin-Yaratılış Kitabı, çev.: Uğur Akpur, Say Yayınları, İstanbul, 2009.

Gündüz, Şinasi vd., Dinlerde Yükseliş Motifleri ve İslam'da Miraç, Vadi Yayınları, Konya, 1996.

Mazkenzie, Donald A., Çin ve Japon Mitolojisi, çev.: Koray Akten, İmge Kitabevi, Ankara, 1995.

Roberts, Jeremy, Chinese Mythology A to Z, Facts on File Press, New York, 2004

Remler, Pat, Eygptian Mythology A to Z, Facts of File Press, New York, 2006.

Schimmel, Annemarie, Sayıların Gizemi, çev.: Mustafa Küpüşoğlu, Kabalcı Yayınevi, İstanbul, 2000.

Schwartz, Howard, Tree of Souls, The Mythology of Judaism, Oxford University Press, New York, 2004.

Türkçe Sözlük, TDK Yayınları, 9. Baskı, Cilt 2, Ankara, 1998.

Williamson, Arthur H., Apocalypse Then, Prophecy and the Making of Modern World, Preager Publishers, London, 2008. 


\section{The Ladder Motif as an Mythological and Religious Ascension Symbol}

Citation/@- Sümer, N. (2018). The Ladder Motif as an Mythological and Religious Ascension Sym-bo, Çukurova University Journal of Faculty of Divinity, 18 (1), 257-269.

Abstract- $A$ ladder is a tool that carries a person from one position to another. The change in position here can be from bottom to top level as well as from top to bottom. The ladder that meets the simple needs of everyday life is a symbol of mythos and religions. The ladder became a tool that allowed the shaman in primitive tribes to climb trees while he was operating the ongoing rituals. Sometimes the ladder was seen as a holy object in the myths, where the Gods land on the earth to communicate with the world by using it. In some religions, the ladder is a symbol of a seesaw in the dreams of the prophets where the angels wander about. The ladder has been used for many purposes but usually identified with the ascension image. People and Gods have often preferred to climb to the top with seven-step ladders. The imaginary ladder that rising to the sky, as well as the sacred temples built on the earth are all in the form of seven-step ladder. In many cultures, on the other hand, is believed that the ladder has gained a meaning and a value both in this world and the other. Therefore, this study focuses on the role of the ladder symbol in myths and in some religious cultures.

Keywords- Ladder, earth, sky, God, ascension 